\title{
DNA sequence variation in the fruit tree Inga inicuil (Leguminosae: Mimosoideae) from contrasting altitude distinguishes two different species
}

\author{
Ma. Teresa P. Pulido-Salas ${ }^{1}$, Dolores González ${ }^{2 *}$, Arturo Pérez-Vázquez ${ }^{3}$ \\ AND FranCISCO LOREA-HERNÁNDEZ ${ }^{2}$
}

Botanical Sciences 94 (4): 673-686, 2016

DOI: $10.17129 /$ botsci.638

\section{Abstract}

Background: Inga inicuil is a leguminous tree in Veracruz, Mexico whose fruits are locally commercialized. One taxonomic hypothesis suggests that $I$. inicuil is a species with a wide altitudinal range, while another segregates $I$. paterno from I. inicuil by altitude and morphology. The aim of this study was to explore variation in non-coding regions from the chloroplast and nuclear genomes within individuals of I. inicuil from contrasting altitude.

Hypothesis: Phylogenetic analyses with sequence data would separate exemplars of I. inicuil in two different species and as the case with other metabolites, the sugar content in the sarcotesta would vary with altitude. Studied species: Inga inicuil

Study site: The mountainous region of Coatepec and the coastal region of Tolome and San Pancho in Veracruz, Mexico.

Methods: Representative individuals of I. inicuil were selected from localities with contrasting altitude. Maximum Likelihood and Bayesian Phylogenetic Inference approaches were used for phylogenetic analyses with sequence data from the ITS1-5.8S-ITS2 and trnL-F. Sugar content in ripe fruit was measured using a refractometer.

Results: Sugar content was not related to altitude or with sequence variation. However, sequences from the $\operatorname{trn} \mathrm{L}-\mathrm{F}$ revealed an insertion/deletion of approximately 309 nucleotides present only in trees growing at the coastal plain. Phylogenetic analyses with sequence data support the hypothesis that I. inicuil and I. paterno are two different species.

Conclusions: The remarkable differences of sequence data from the trnL-F within the species make necessary further research increasing taxon sampling along with its distribution range for clarifying its taxonomy.

Key words: edible fruit, indel, Inga paterno, molecular phylogeny, sequence variation.

\section{La variación en las secuencias de ADN en el árbol frutal Inga inicuil (Legumino- sae: Mimosoideae) de altitud contrastante distingue dos especies diferentes}

\section{Resumen}

Antecedentes: Inga inicuil es una leguminosa arbórea en Veracruz, México cuyo fruto se comercializa localmente. Una hipótesis taxonómica sugiere que I. inicuil es una especie con amplio rango altitudinal, mientras que otra segrega I. paterno de I. inicuil por su altitud y morfología. El objetivo de este estudio fue explorar la variación en regiones no codificadoras del cloroplasto y núcleo en individuos de I. inicuil de altitud contrastante.

Hipótesis: Análisis filogenéticos con secuencias génicas separarán ejemplares de I. inicuil en dos especies diferentes, como en otros metabolitos el contenido de azúcar en la sarcotesta variará con la altitud.

Especie en estudio: Inga inicuil

Sitio de estudio: La región montañosa de Coatepec y la región costera de Tolome y San Pancho en Veracruz, México.

Métodos: Se seleccionaron individuos de I. inicuil de localidades con altitud contrastante. Se utilizó Máxima Verosimilitud e Inferencia Filogenética Bayesiana para los análisis filogenéticos con las secuencias del ITS15.8S-ITS2 y del trnL-F. El contenido de azúcar en la fruta madura se midió con un refractómetro.

Resultados: El contenido de azúcar no está relacionado con altitud o variación de las secuencias. Sin embargo, las secuencias del trnL-F revelaron una inserción/deleción de aproximadamente 309 nucleótidos solo en los árboles que crecen en la planicie costera. Los análisis filogenéticos apoyan la hipótesis de que $I$. inicuil e $I$. paterno son dos especies diferentes.

Conclusiones: Las notables diferencias en los datos de secuencias del trnL-F hacen necesario investigación adicional aumentando el muestreo a lo largo del rango de distribución de esta especie para aclarar su taxonomía.

Palabras clave: árbol frutal, filogenia molecular, indel, Inga paterno, variación de secuencias. 
nga inicuil Schltdl. \& Cham. ex G. Don (Ingeae, Mimosoideae, Leguminosae) is a tree native to Mesoamerica where it is used as a shade tree in coffee plantations (Pennington \& Sarukhán 1998). In the mountainous region of Coatepec, Veracruz, Mexico this tree and fruit are commonly known as "jinicuil". The seeds are appreciated for their sweetness fleshy sarcotesta and the pods are sold as fresh fruit. Jinicuil is also the common name used at the coastal plains of Veracruz, where people there eat the seeds cooked and salted as a snack. The cotyledons contain protein (Geilfus 1994, Bressani 2010) and germination can reach $100 \%$ (Pennington 1997), which gives the species high potential as a food crop. Additionally, pods are sold in local markets in Coatepec. In spite of its cultural importance, there is not any agricultural management of the tree and the rate of local loss of trees in this area has been estimated at $2.4 \%$ annually (Pulido-Salas 2009, 2013).

One challenge in achieving agricultural sustainability is the development of agroecosystems with a predominance of native species (Altieri \& Nicholls 2000). To accomplish this, it is necessary to learn more about these species (Vázquez-Yanes et al. 1999) as well as characterize them in order to design specific management programs (Martínez-Castillo et al. 2004). The diversity and genetic structure of populations constitute a basic starting point for developing management protocols for native species or for initiating genetic conservation programs. If biodiversity is not preserved, heterozygosity may be reduced and introgression can occur with the concomitant deterioration of local genetic populations and of the species itself (Baverstock \& Moritz 1996). Knowing the genetic diversity of native species allows for the development of long-term programs to manage, monitor, and preserve populations (Karp et al. 1997). To achieve this, molecular approaches allow the identification of polymorphisms in different regions of the genome with various mutation rates (Parker et al. 1998). There are several molecular techniques for exploring genetic diversity. Both Amplified Fragment Length Polymorphisms (AFLPs) and Random Amplified Polymorphic DNA (RAPDs) can detect genetic variation across the entire genome. Others include Restriction Fragment Length Polymorphisms (RFLPs), Simple Sequence Repeats (SSR, microsatellites) or genic sequences (González 1998), which can detect variation in more specific regions of the genome. For example, in an AFLP study with 56 samples of 30 varieties of Macadamia spp., it was possible to quantify the degree of polymorphism in the varieties and their progenitors, and to propose a possible differentiated agricultural management (Robledo 2003). In another study, using RFLP (Restriction Fragment Length Polymorphism) markers in fragmented populations of Sorbus torminalis, a species appreciated for its fruit and wood, significant genetic variation was found that could be attributed to recent changes in silvicultural practices in Central Europe (Angelone et al. 2007). Also, a study with SSR markers for the characterization and analysis of genetic diversity in cultivars of Corylus avellana found high genetic diversity and polymorphism that was suitable for distinguishing different hazelnut lineages (Bassil et al. 2013). Furthermore, research with DNA sequence of non-coding regions has also provided insight into genetic diversity in a variety of organisms because these segments of DNA are less functionally constrained and are, therefore, more variable (González \& Vovides 2002). For example, a study with the trnH-trnK non-coding region of chloroplast DNA sequence data in apricot germplasm revealed significant genetic diversity of nucleotide sequences in both haplotypic and nucleotide diversity tests. The results provided some clues for the origin of apricot species and useful information for the management of apricot genetic resources (Batnini et al. 2014).

There are few studies on genetic diversity for species of Inga, particularly for I. inicuil and I. paterno Harms. Those that exist focus mainly on the preservation of species in tropical forests, such as I. edulis (e.g. Hollingsworth et al. 2005, Dawson et al. 2008, Rollo et al. 2016), I. thibaudiana (Schierenbeck et al. 1997), and I. vera (Cruz-Neto et al. 2014). Other studies of Inga have proposed hybridization between species that grow together in coffee plantations. Pennington (1997) recorded seven species that were auto-incompatible and inter-sterile and observed that the best fruit of I. inicuil (i.e. longer pods and sweeter sarcotesta) was on trees separated by over one kilometer. The possibility of hybridization, however, has not been proven genetically.

On the other hand, chemical studies of Inga species have discovered a relationship between altitude and the amount of some chemical compounds. For example, it has been found that the amount of pipeolitic acid (a non-proteinic amino acid) in the leaves of several species varies according to altitude. Although I. inicuil was not included in that study, it was shown that species 
growing at a similar altitude have similar patterns of pipeolitic acid, which is interpreted as a defense strategy against predators or pathogens such as ants and fungi (Morton et al. 1991, Kite 1997). Also, Koptur (1985) reported varying concentrations of phenolic compounds in leaves of I. densiflora and I. punctata that are also correlated with altitude. Nonetheless, it is unknown if there is a connection between altitude and sugar content in the fruit of I. inicuil.

Inga has great morphological variation (Pennington 1997). It is considered a genus in the process of diversification (Richardson et al. 2001). It includes around 300 species within the tropical Americas, ranging in altitude from sea level to 3,000 m. The genus has had a complex taxonomic history and unstable nomenclature (e.g. Sousa 1993, 2001, 2009, Pennington 1997, Brown et al. 2008). Currently, two taxonomic hypotheses exist for I. inicuil. The first states that what is commonly known as "jinicuil" belongs to two species described as I. inicuil and I. paterno, with morphological differences and separated by altitude (Sousa 1993, 2001, Ricker et al. 2013). Inga paterno was described having stipules persistent, from 9 to $22 \mathrm{~mm}$ long, and pedicel thin, up to $5 \mathrm{~mm}$ long growing between 0-800 $\mathrm{m}$ a.s.l.; while I. inicuil has stipules soon deciduous, from 5 to $9 \mathrm{~mm}$ long, and pedicel short and robust, of $1.5 \mathrm{~mm}$ long and grows above $850 \mathrm{~m}$ a.s.l. The second hypothesis proposes that jinicuil is a single species (I. inicuil) with a wide altitudinal distribution, spanning from the mountainous cloud forest to the regions with evergreen and sub-deciduous forests near sea level and with wide ranges of morphological variation (Pennington 1997). Under this scenario the name I. paterno falls into synonymy with the older name I. inicuil (Pennington 1997, Pennington \& Sarukhán 1998, Groom 2012). In a phylogenetic analysis with nuclear and chloroplast DNA, the genus Inga as a whole was shown to be monophyletic. However, very little variation was found in the sequences generating unresolved topologies, which led to the conclusion that Inga represents a recently diversified genus (Richardson et al. 2001). In a molecular phylogenetic analysis aimed at elucidating the evolution of defenses to herbivory in the genus, several species of Inga were analyzed (Kursar et al.2009), and the results confirmed the lack of variation within species of Inga. None of these studies included I. inicuil or I. paterno. The aim of this study was to explore variation in sequences of non-coding regions from the chloroplast and nuclear genomes within individuals of I. inicuil from contrasting altitude. We hypothesized that phylogenetic analyses with sequence data would separate exemplars of I. inicuil in two different species and as the case with other metabolites, the sugar content in the sarcotesta would vary with altitude.

\section{Materials and methods}

Material studied. From 57 located trees, 22 adult individuals were selected (DBH $>15 \mathrm{~cm}$ ). Trees were not physically close to each other to avoid possible kinship, and were chosen from contrasting altitude. From these, 19 were from the municipality of Coatepec, Veracruz, located between 850 and 1,530 m a.s.l. on the edge of the central mountainous region of Mexico and were used as shade trees in coffee plantations, while three were from the town of Tolome, municipality of Paso de Ovejas, Veracruz in the coastal region at $50 \mathrm{~m}$ a.s.l. Fertile branches/ samples from the chosen trees were collected for herbarium specimens and some were also sent to a taxonomist specialist on Inga for an accurate identification. Representative collections were deposited at the herbaria XAL, Instituto de Ecología, A. C. in Xalapa, Veracruz and MEXU, Instituto de Biología, Universidad Nacional Autónoma de México in Mexico City.

Sugar content in fruit. Given that the sweetness of the pulp covering the seeds is one of the characteristics that increases the commercial potential of I. inicuil, and with the hypothesis that, as in the case with other metabolites, there could be a connection between altitude and sugar content, we took a sample of 16 pods per tree from 19 trees from the mountain region and three from the coastal region, four for each quarter of an imaginary square on the crown (Martínez-Moreno et al. 2006). The sugar content was measured ( ${ }^{\circ} \mathrm{Bx}$ average/tree) in ripe fruit of the juice coming out from the sarcotesta using a refractometer (ATAGO ATC-1; range $0-32{ }^{\circ} \mathrm{Bx}$ ) during the summer. The four highest values per tree were used to calculate the average. Different seeds from the same pod were measured separately. The Pearson correlation coefficient was measured in Excel. 
DNA extraction and amplification. For DNA extraction, 25 representative trees were selected from localities with contrasting altitude (Table 1). Twelve were from the mountainous region (municipality of Coatepec) and 13 from the coastal region (three from Tolome and ten from San Pancho, in the municipalities of Paso de Ovejas and La Antigua, respectively). Genomic DNA was extracted from young recently collected leaves, as suggested by Doyle \& Doyle (1987). Extraction and purification of DNA was conducted with the DNeasy plant mini kit (Qiagen, Valencia, CA, USA), following the instructions of the manufacturer. To verify the quantity and quality of the DNA, an aliquot was taken from the extraction and loaded in a $1.2 \%$ agarose gel dyed with ethidium bromide. A molecular-weight marker of known concentration $(25 \mathrm{ng} / \mu \mathrm{l})$ was included in the gel. Each sample was amplified with specific primers for two molecular markers, one nuclear and the other from chloroplast. The nuclear marker corresponded to the ITS1-5.8SITS2 region (ITS), and the chloroplast marker to a section of the trnL-F intergenic spacer. Primers used for amplifying the ITS were ITS1 (5'- TCCGTAGGTGAACCTGCGG -3') and ITS-4 (5'-TCCTCCGCTTATTGATATGC-3'; White et al. 1990). Primers for the $\operatorname{trn} \mathrm{L}-\mathrm{F}$ were "e" and "f”' (5'-GGTTCAAGTCCCTCTATCCC-3' and 5'-ATTTGAACTGGTGACACGAG-3' respectively; Taberlet et al. 1991). Reactions were performed in a $25 \mu 1$ mixture containing 10-20 ng of DNA, $5 \mu \mathrm{l}$ of PCR buffer, $200 \mu \mathrm{M}$ of each of the four deoxynucleoside triphosphates, 5 pmol of each primer, $2.5 \mathrm{mM} \mathrm{MgCl}, 2.5 \mathrm{U}$ of Go Taq flexi DNA polymerase (Promega, Madison, WI, USA), and distilled water to volume. The amplifications were performed on a thermocycler (Mastercycler, Eppendorf, Hamburg, Germany). The amplification program included an initial denaturation at $94{ }^{\circ} \mathrm{C}$ for $5 \mathrm{~min}$, followed by 35 cycles with denaturation at $94{ }^{\circ} \mathrm{C}$ for $1 \mathrm{~min}$, annealing at $51-59^{\circ} \mathrm{C}$ for $1 \mathrm{~min}$, and extension at $72^{\circ} \mathrm{C}$ for $2 \mathrm{~min}$, and a final extension for 7 $\min$ at $72{ }^{\circ} \mathrm{C}$.

Table 1. Municipality, altitude and GenBank accession numbers for specimens used in phylogenetic analyses. *indicates specimens with an insertion/deletion (indel) of about $309 \mathrm{bp}$ in the trnL-F region.

\begin{tabular}{|c|c|c|c|c|}
\hline \multirow{2}{*}{$\begin{array}{l}\text { Collection } \\
\text { code }\end{array}$} & \multirow{2}{*}{$\begin{array}{l}\text { Municipality } \\
\text { (Veracruz, Mexico) }\end{array}$} & \multirow{2}{*}{$\begin{array}{l}\text { Altitude } \\
\text { (m a.s.I.) }\end{array}$} & \multicolumn{2}{|c|}{ GenBank accession number } \\
\hline & & & ITS & trnL-F \\
\hline MS III & Coatepec & 850 & KR186220 & KR186245 \\
\hline JMcv I & Coatepec & 1,050 & KR186221 & KR186246 \\
\hline JMcv II & Coatepec & 1,050 & KR186222 & KR186247 \\
\hline JMcv IV & Coatepec & 1,050 & KR186223 & KR186248 \\
\hline JMor IV & Coatepec & 1,060 & KR186224 & KR186249 \\
\hline MA III & Coatepec & 1,150 & KR186225 & KR186250 \\
\hline CG I & Coatepec & 1,150 & KR186226 & KR186251 \\
\hline CG III & Coatepec & 1,150 & KR186227 & KR186252 \\
\hline TS III & Coatepec & 1,150 & KR186228 & KR186253 \\
\hline RR I & Coatepec & 1,260 & KR186229 & KR186254 \\
\hline JB I & Coatepec & 1,528 & KR186230 & KR186255 \\
\hline JB II & Coatepec & 1,350 & KR186231 & KR186256 \\
\hline RoTo & Paso de Ovejas & 50 & KR186232 & *KR186257 \\
\hline CaTo & Paso de Ovejas & 50 & KR186233 & *KR186258 \\
\hline 3Тo & Paso de Ovejas & 50 & KR186234 & *KR186259 \\
\hline M5 & San Pancho & 20 & KR186235 & *KR186260 \\
\hline M5-A & San Pancho & 20 & KR186236 & *KR186261 \\
\hline M6 & San Pancho & 20 & KR186237 & *KR186262 \\
\hline M6-A & San Pancho & 20 & KR186238 & *KR186263 \\
\hline M7 & San Pancho & 20 & KR186239 & *KR186264 \\
\hline M7-A & San Pancho & 20 & KR186240 & *KR186265 \\
\hline M8 & San Pancho & 20 & KR186241 & *KR186266 \\
\hline M8-A & San Pancho & 20 & KR186242 & *KR186267 \\
\hline M9 & San Pancho & 20 & KR186243 & *KR186268 \\
\hline M9-A & San Pancho & 20 & KR186244 & *KR186269 \\
\hline
\end{tabular}


DNA sequencing and analyses. Amplified DNA was purified before sequencing with the Wizard SV gel and PCR clean-up system kit as described by the manufacturer (Promega, Madison, WI, USA), and sequenced using ABI PRISM BigDye Terminator v3.1 Cycle Sequencing Kit (Applied Biosystems, Foster City, CA, USA) according to manufacturer's instructions. Cycle sequence products were cleaned with an isopropanol precipitation and electrophoresed using an ABI 310 genetic analyzer (Applied Biosystems, Foster City, CA, USA). The resulting sequences were edited with BioEdit software version 7.1.3.0 (Hall 1999) and aligned using ClustalW with default parameters for gap opening and extension penalties (Thompson et al. 1994). Sequence variation was obtained using the Arlequin software v. 3.1 (Excoffier et al. 2005). Phylogenetic analyses of sequence data were performed separately and combined with Maximum Likelihood (ML) using GARLI v. 0.951 (Zwickl 2006) and Bayesian Phylogenetic Inference (BPI) using MrBayes 3.1.2 (Huelsenbeck \& Ronquist 2001, Ronquist \& Huelsenbeck 2003, Altekar et al. 2004). BPI analyses were executed with model parameters GTR $+\Gamma(\mathrm{nst}=6$; rates $=$ gamma $)$, and default values for priors. ML analyses were performed specifying in the script that model parameters were computed at the same time during the searches. Analyses consisted of 10 replicates to ensure that results were consistent and reproducible. Branch support for ML was determined simultaneously by performing 100 non-parametric bootstrap iterations in each of the 10 replicates. BPI analyses comprised two independent 1-million generation runs, with four chains (one cold and three hot) each, until an average standard deviation of split frequencies of 0.01 or less was reached. We sampled trees every $100^{\text {th }}$ generation and discarded initial samples applying a "burnin" value of $25 \%$ before calculating the majority consensus tree and posterior probabilities (PP) for clades.

Four matrices were prepared for analyses. One included only trnL-F sequences from 69 terminals. They corresponded to twenty-five sequences generated in this study (12 from the mountainous region and 13 from the coastal plains), and 38 from GenBank. From the GenBank sequences, 28 correspond to identified Inga species (I. alba, I. edulis and I. thibaudiana with two, four and two representatives respectively), five to non-identified Inga spp., and six to representatives from the tribe Ingeae, which were used as the outgroup (Zapoteca sousae, Pithecellobium diversifolium, Abarema piresii, and three for Zygia spp.). Two matrices contained only ITS sequences. One comprised 464 terminals, 25 from this study and 434 from GenBank. From these, 45 correspond to identified Inga species (some species having up to 27 representatives), 52 to non-identified Inga spp., and five representatives from the outgroup. Other matrix had only 110 terminals. This included 25 from this study, two of each identified Inga species (10 species with only one) and the representatives of the tribe Ingeae. A concatenated matrix was also constructed. This included the 25 terminals from this study, two species of Inga with same voucher (I. edulis and I. thibaudiana) that have sequences in GenBank for both loci, and three representatives of the tribe Ingeae. All cladograms were edited with Adobe Illustrator v 13.0.2. Alignment and resulting trees from multi-locus gene analyses are deposited in TreeBASE (http://purl.org/phylo/treebase/phylows/study/TB2:S17506).

\section{Results}

Sugar content and sequence analyses. The analysis of sugar content in the fruits revealed unexpected variation. Values obtained do not show any discernible pattern (Figure 1) and are not homogeneous among seeds even in the same pod. For example, data obtained from seeds in one of the pods tested varied from 13 to $18^{\circ} \mathrm{Bx}$. There was also no relationship of sugar content and altitude (Figure $2 ; r^{2}=-0.05$ ) or a relationship of sugar content with DNA sequence variation.

The results for sequence data confirmed that sequences from both loci had little variation. Nevertheless, DNA sequences from ITS and trnL-F in exemplars from the coastal and mountainous regions varied according to altitude. The $\operatorname{trn} \mathrm{L}-\mathrm{F}$ region did not have any nucleotide substitution among the 25 obtained sequences, but there was an insertion/deletion (indel) of about 309 base pairs (bp) exclusively in the 13 trees from the coastal region (marked with an asterisk in Table 1). The sizes of the amplicons for the trnL-F with the primers e-f were $495 \mathrm{bp}$ for the 12 exemplars from the mountain region and $186 \mathrm{bp}$ for the 13 trees from the coastal region (Figure 3 ). This indel is not present in any of the 33 species of Inga that have sequences for this locus 
Figure 1. Values of sugar content in each tree and its ranges of variability.

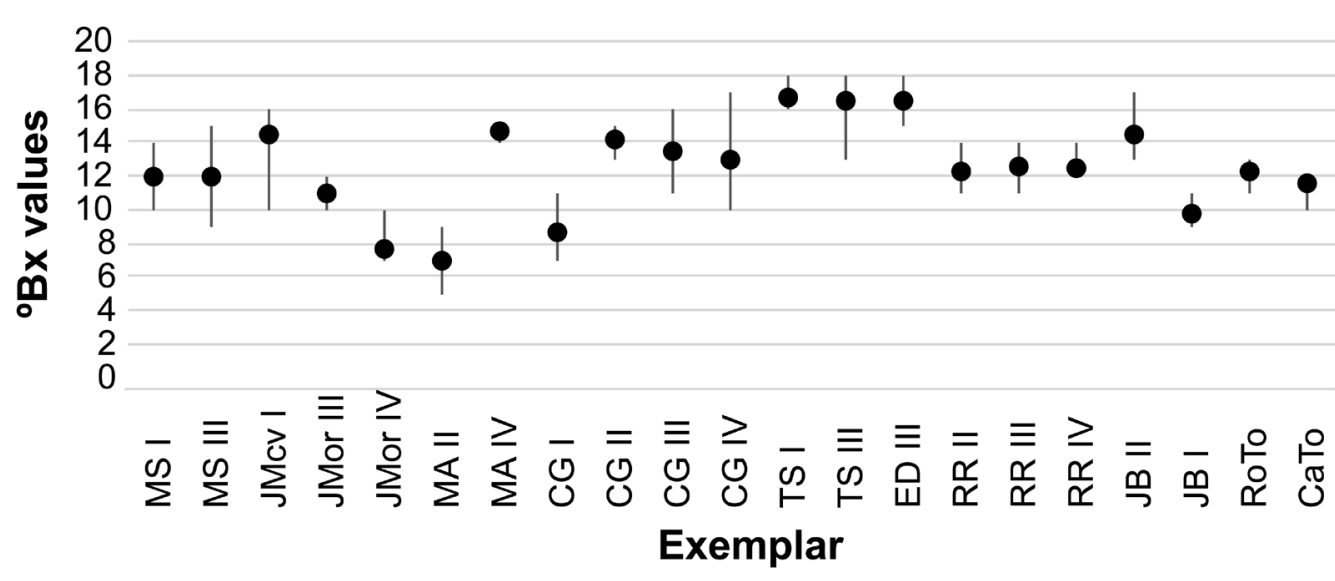

Figure 2. Relationship between altitude and sugar content in the fleshy seedcoat of Inga inicuil.

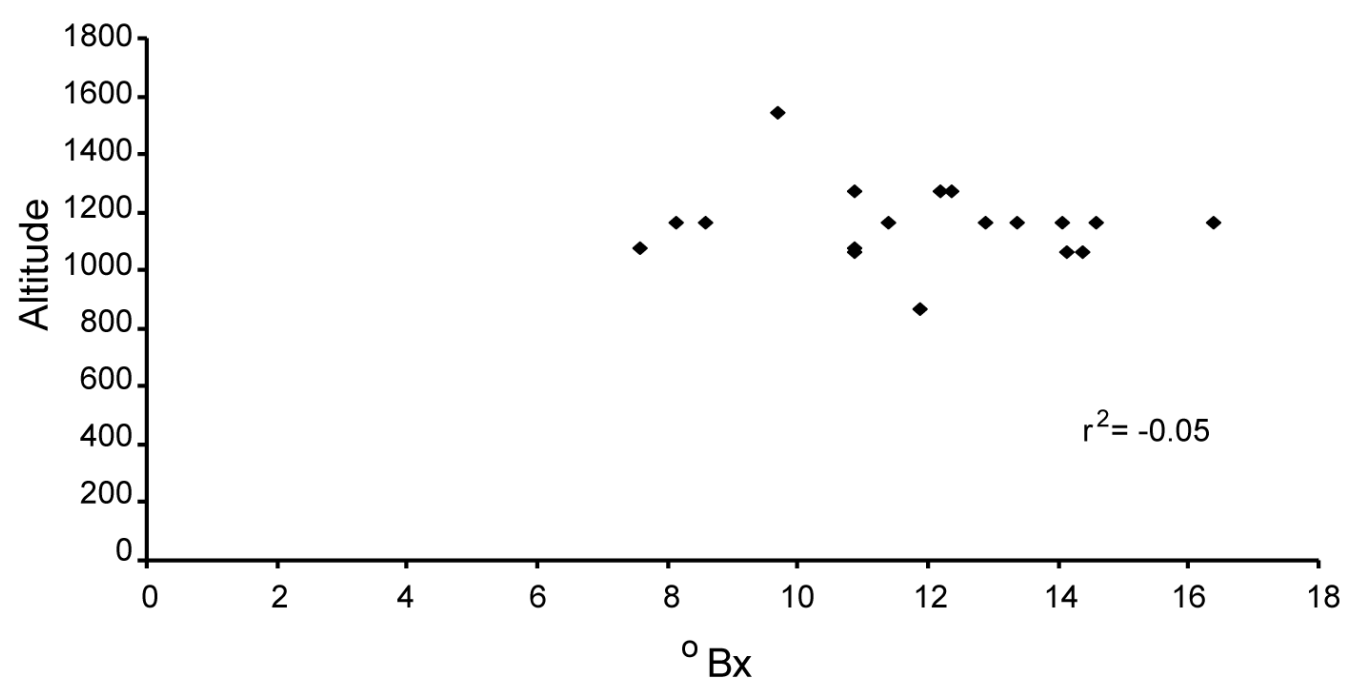

in GenBank. In contrast, sequences from the ITS have only nucleotide substitutions among the 25 sequences obtained in this study. The size of the amplicon for the ITS with the primers ITS1ITS4 was 657 bp (Table 2). As with the trnL-F locus, there was distinctive variation in nucleotide substitutions for the 13 exemplars from the coastal plains (Figure 4) among 437 exemplars of Inga that have ITS sequences in GenBank.

Phylogenetic analyses. ML and BPI analyses with the trnL-F locus and 69 terminals generated unresolved cladograms (Figure 5). Low DNA sequence variation was a problem for the analy-

Table 2. Summary of sequence variation in the fruit tree Inga inicuil. Most of the polymorphic sites are due to the indel in exemplars from the coastal region.

\begin{tabular}{crccccccc}
$\begin{array}{c}\text { Gene } \\
\text { partition }\end{array}$ & $\begin{array}{r}\text { Tree } \\
\text { Provenance and } \\
\text { (number) }\end{array}$ & $\begin{array}{c}\text { Amplicon } \\
\text { size (bp) }\end{array}$ & $\begin{array}{c}\text { After } \\
\text { alignment }\end{array}$ & $\begin{array}{c}\text { No. of } \\
\text { polymorphic } \\
\text { sites }\end{array}$ & Ts Tv & $\begin{array}{c}\text { Indels } \\
\text { of one } \\
\text { nucleotide }\end{array}$ & $\begin{array}{c}\text { Longer } \\
\text { indels (bp) }\end{array}$ \\
\hline trnL-F & $\begin{array}{r}\text { Mountainous } \\
\text { region (12) }\end{array}$ & 495 & 495 & 316 & 6 & 1 & 1 & $1(309)$ \\
\hline Coastal region (13) & 186 & & & 14 & 12 & 0 & 0 \\
\hline & $\begin{array}{r}\text { Mountainous } \\
\text { region (12) } \\
\text { Coastal region (13) }\end{array}$ & 657 & 657 & 14 & & & \\
\hline
\end{tabular}




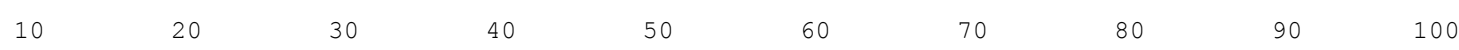

MS III TCTCTATTATTTATCCTATATCCTCTTTTTTTTTTTAGTGGTTCAAATTCGTTATGTTTCTTATTCATTCTATTCTTTCACAACGGATCTGAGTGGA

JB II

RoTo

CaTo

$$
\text { СтСта. }
$$

СТСТА.

110

120

130

140

150

160

170

180

190

200

$\ldots . \ldots|\ldots| \ldots|\ldots| \ldots|\ldots| \ldots|\ldots| \ldots|\ldots| \ldots|\ldots| \ldots|\ldots| \ldots|\ldots| \ldots|\ldots| \ldots|\ldots| \ldots|\ldots| \ldots|\ldots|$

MS III

JB II

RoTo

CaTo

MS III

JB II

ROTO

CaTo

210

220

230

240

250

260

270

280

290

300

$\ldots . \ldots|\ldots| \ldots|\ldots| \ldots|\ldots| \ldots|\ldots| \ldots|\ldots| \ldots|\ldots| \ldots|\ldots| \ldots|\ldots| \ldots|\ldots| \ldots|\ldots| \ldots|\ldots|$ АTСTTTGAGCAAGGATCCTCATTTGACTGATTAACAATACATATCATTACTCCGACTGAAACATACAAA GTCTTATTTTGGAAGATCCAAGAAATCTA

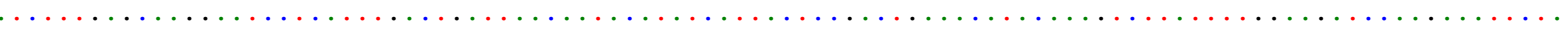

310

320

330

340

350

360

370

380

390

400

MS III

JB II

ROTO

Сато

$\ldots . \ldots|\ldots| \ldots|\ldots| \ldots|\ldots| \ldots|\ldots| \ldots|\ldots| \ldots|\ldots| \ldots|\ldots| \ldots|\ldots| \ldots|\ldots| \ldots|\ldots| \ldots|\ldots| \ldots|\ldots|$ GGGCTTGGATGAAACTTTGTAATTCTTTTTCGTCTTTTTTTTTTAGTTGACATATACTCAAGTAATCTCTTAAAATGAAGATGATGCGTCACGAAAGGTC

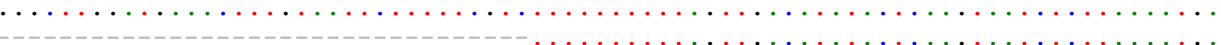

G.

Figure 3. Sequence alignment of a section of the trnL-F gene in four exemplars of Inga showing the large indel in exemplars of the coastal plains (Roto and CaTo). MS III and JB II were collected from the mountainous region.

10

20

30

40

50

60

70

80

90

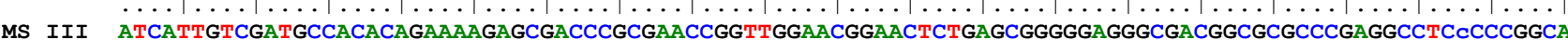

JB II

RoTo

CaTo

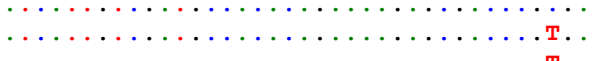

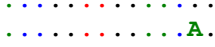

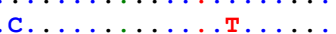

$\ldots \ldots \ldots$

130

140

150

160

170

180

190

200

MS III ACCAAACCCCGGCGCCCAGGCGCCAAGGAACGAAAAGAGCGGGGACGCCCGCCGGCGGCGCCGGCGTGGCGTCTCATGCCATTTGGATCCGAAATG

JB II

RoTo

CaTo

\begin{tabular}{ccccccccc}
210 & 220 & 230 & 240 & 250 & 260 & 270 & 280 & 290 \\
\hline
\end{tabular}

MS III ACTCTCGGCAACGGATATCTCGGCTCTCGCATCGATGAAGAACGTAGCGAAATGCGATACTTGGTGTGAATTGCAGAATCCCGTGAACCATCGAGTCTTT

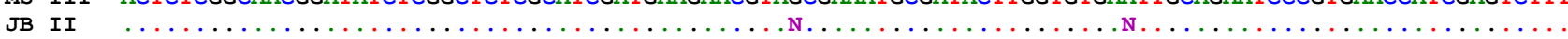

RoTO

CaTo

320

330

340

350

360

370

380

390

400

MS III

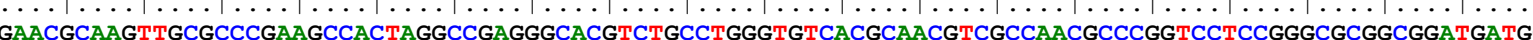

JB II

RoTo

CaTo

$\ldots \ldots \ldots \ldots \ldots \ldots \ldots \ldots \ldots \ldots$

$440 \quad 450$

460

470

480

490

500

$\ldots \ldots|\ldots| \ldots|\ldots| \ldots|\ldots| \ldots|\ldots| \ldots|\ldots| \ldots|\ldots| \ldots|\ldots| \ldots|\ldots| \ldots|\ldots| \ldots|\ldots| \ldots|\ldots| \ldots|\ldots| \ldots|\ldots| \ldots|\ldots| \ldots \mid$

MS III CCTCCCGGGGCCTCGCCCCCGGCCGGCGAAAAAGGGCCCGACGTGACGACCGCCACGATCCACGGTGGTTGAGCGGACACCCGCTCGAGGCCATGA

JB II

RoTo

Сато

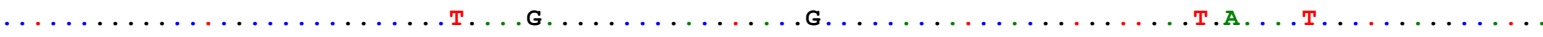

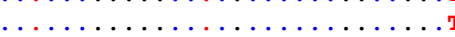

510

520

530

540

550

560

570

580

590

ROTO

CaTo

Figure 4. Sequence alignment of a section of the ITS gene in four exemplars of Inga showing differences in nucleotide substitutions between exemplars from the coastal plains (Roto and CaTo), and from the mountainous region (MS III and JB II). 
Figure 5. Phylogenetic tree for the $\operatorname{trn} \mathrm{L}-\mathrm{F}$ spacer showing the topological placement of Inga's exemplars from the mountainous and coastal regions relative to other Inga spp. Analysis was performed with Maximum Likelihood. Values of support are indicated above branches (ML bootstrap/PP).

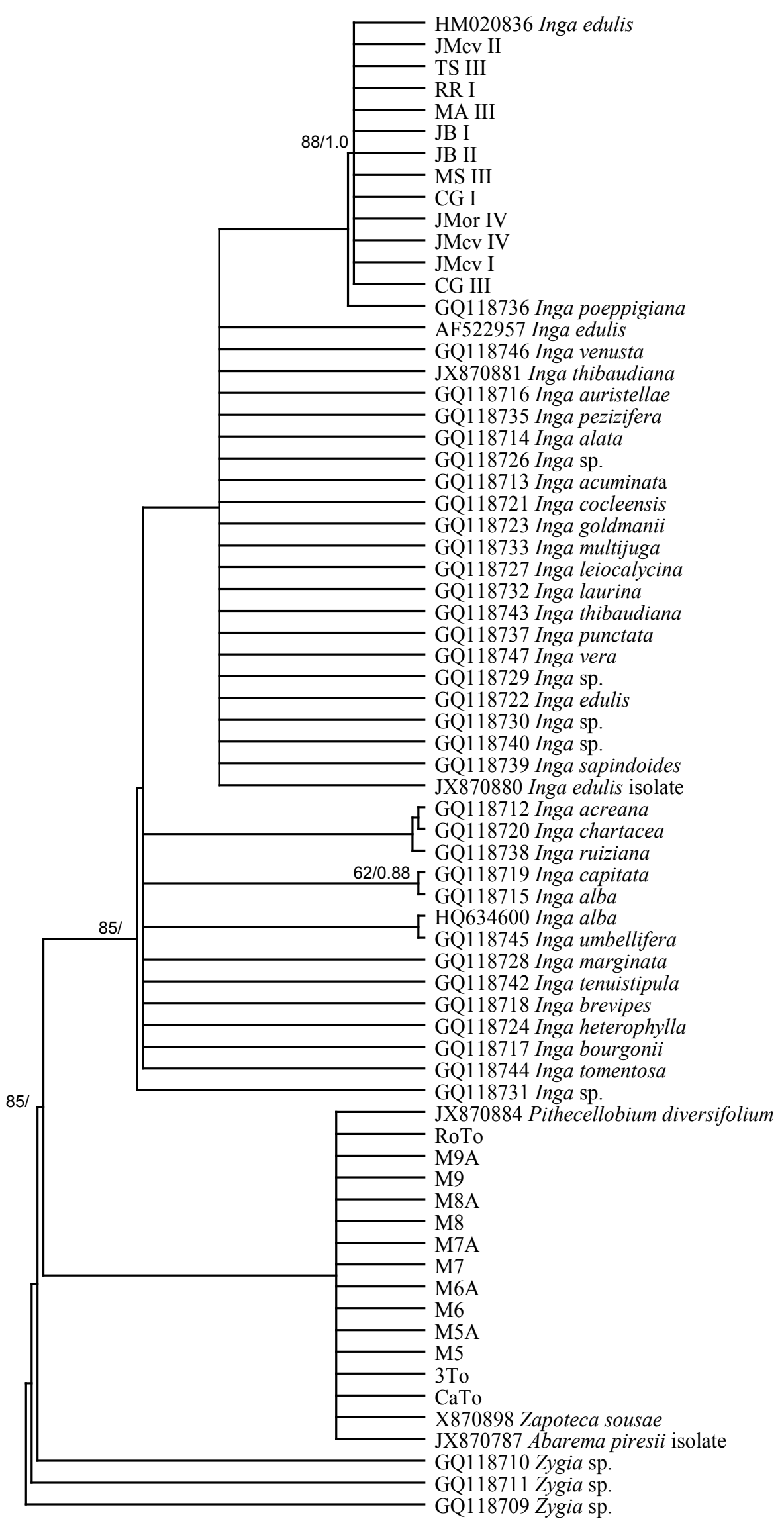


Figure 6. Phylogenetic tree for the ITS region showing the topological placement of Inga's exemplars from the mountainous and coastal regions relative to other Inga spp. Analysis was performed with Maximum Likelihood. Values of support are indicated above branches (ML bootstrap/PP).

10.97 GU013070 Inga fosteriana Gu 12924 Inga barbata GU013408 Inga vera GU013355 Inga thibaudiana GU013142 Inga macrophylla GU013141 Inga longipes GU013079 Inga ingoldes GU013078 Inga ingoides GU013059 Inga edulls GU012925 Inga barbata 10.92 G GU013037 Inga densiflora GU013040 Inga densiflora GU013197 Inga poeppigiana

$$
\text { (n) }
$$

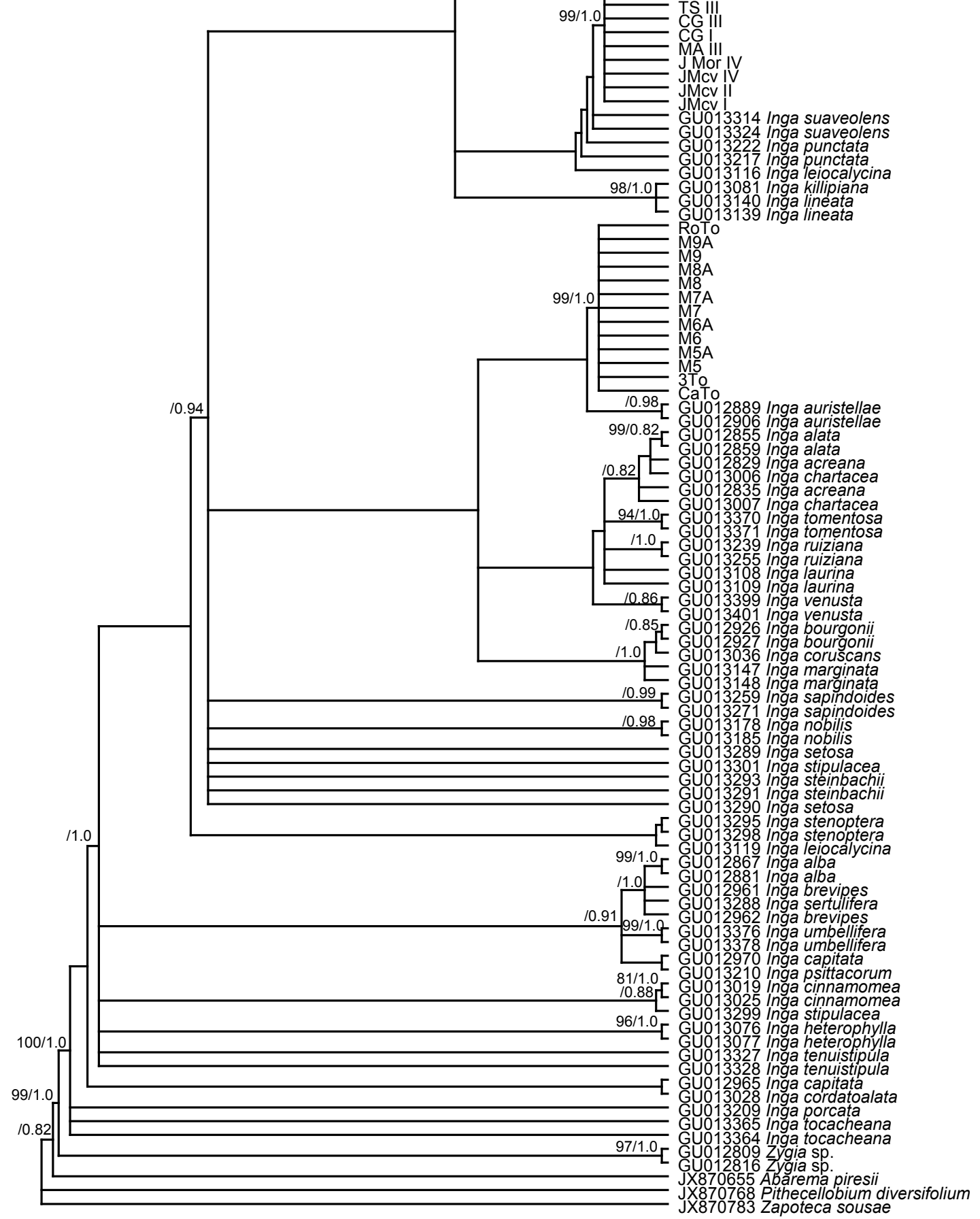


Figure 7. Hypothesis of inferred relationships of Inga inicuil and I. paterno, based on Maximum Likelihood of the concatenated data set of two loci (ITS and trnL-F). Values of support are indicated above branches (ML bootstrap/PP).

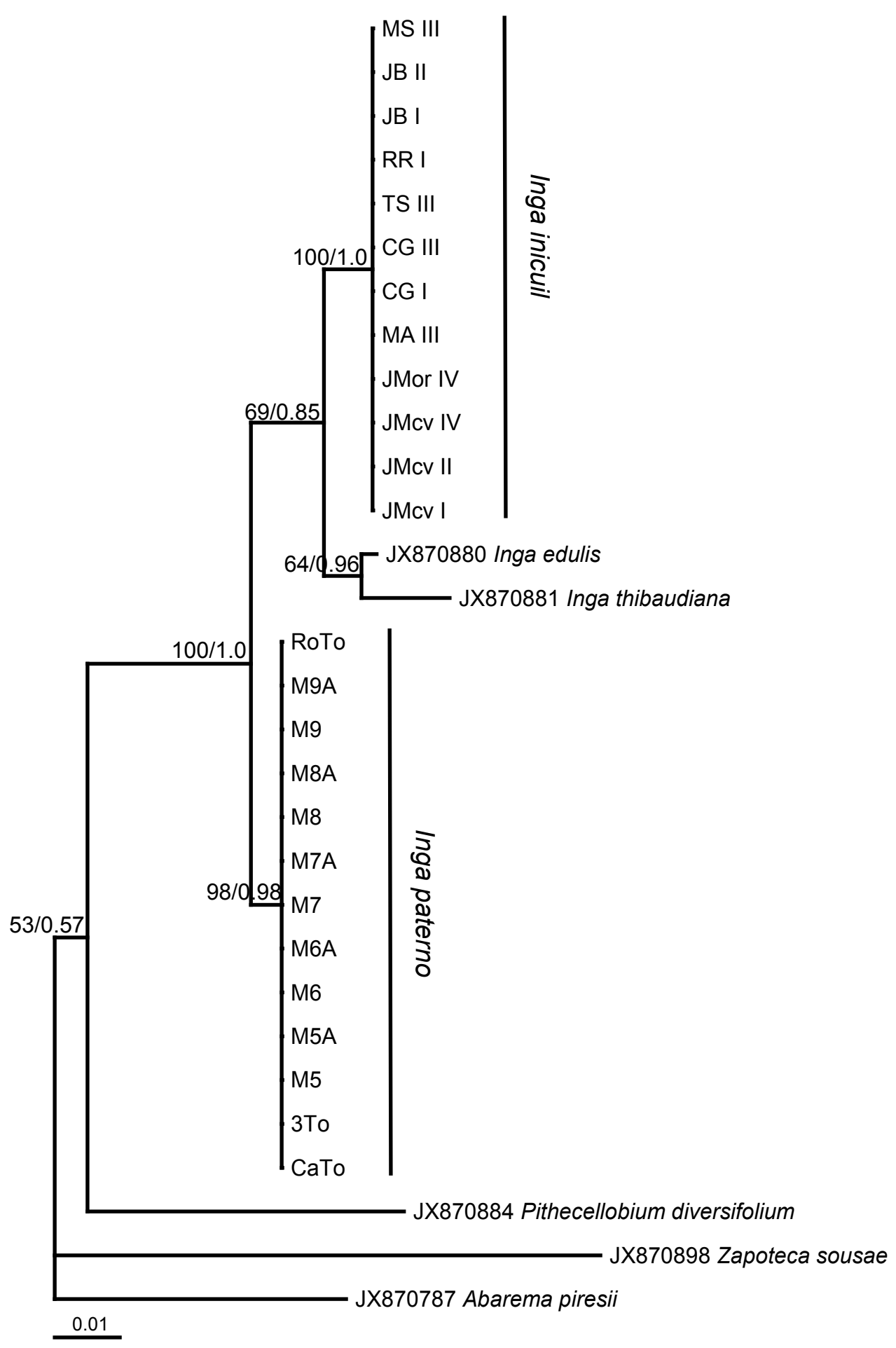

ses due to few characters. The best tree from the ML analysis had a $\log$ likelihood (-lnL) score of -1333.8458 and revealed a relationship between the 13 exemplars from the coastal plains and Pithecellobium diversifolium, Zapoteca sousae, and Abarema piresii. However, this result is very likely artificial since it is the result of lack of characters in the sequences with the 309 bp indel. In contrast, ML analysis with the matrix of 464 sequences for the locus ITS generated a tree with several groups in terminal branches, but without resolution in basal branches (not shown), supporting the proposed recent divergence of the species within this genus. In the second ML analysis with only 110 ITS sequences $(-\operatorname{lnL}=2755.6728)$, Inga auristellae was the 
Table 3. Comparative features of Inga inicuil and I. paterno

\begin{tabular}{ccccl}
$\begin{array}{c}\text { Collection } \\
\text { code }\end{array}$ & $\begin{array}{c}\text { Collector number } \\
\text { (Pulido-Salas) }\end{array}$ & $\begin{array}{c}\text { Locality, } \\
\text { Ver., Mexico }\end{array}$ & $\begin{array}{c}\text { Identified } \\
\text { taxon }\end{array}$ & $\begin{array}{l}\text { Distinctive morphological } \\
\text { characters (Sousa 1993) }\end{array}$ \\
\hline RoTo & 1016 & Tolome & I. paterno & Altitude: $0-800 \mathrm{~m}$ above sea level \\
CaTo & 1015 & Tolome & I. paterno & $\begin{array}{l}\text { Stipules: persistent, from } 9 \text { to } 22 \mathrm{~mm} . \\
\text { Pedicel: thin, up to } 5 \mathrm{~mm} \text { long. }\end{array}$ \\
\hline TS III & 1031 & Coatepec & I. inicuil & Altitude: $1400-2400 \mathrm{~m}$ above sea level \\
RR I & 1034 & Coatepec & I. inicuil & Stipules: soon deciduous, from 5 to $9 \mathrm{~mm}$. \\
JB I & 1037 & Coatepec & I. inicuil & Pedicel: short and robust, of $1.5 \mathrm{~mm}$ long
\end{tabular}

sister group to the 13 exemplars of the coastal plains and I. suaveolens to the 12 exemplars of the mountainous region (Figure 6). Our results indicate that the sequences generated in this study do not correspond to any of Inga species deposited in GenBank. Analyses of ML and BPI of combined sequence data showed a clear distinction between the exemplars of the coastal plains and the mountainous region. Both clades had high support values. Clade containing exemplars of the coastal plains had a bootstrap value of $98 \%$, and a PP of 0.98 while clade containing exemplars from the mountainous region had 100 and 1.0 respectively (Figure 7). ML analysis recovered a tree with a log likelihood score of -3106.1068 . Consequently, molecular data and morphologically distinctive characters noted by the taxonomist of the genus on herbarium specimens (Table 3) show clearly that both sources of information distinguish between exemplars from the mountainous region and the coastal region, supporting the hypothesis that they are two different species.

\section{Discussion}

Variation in the sugar content of the sarcotesta did not support one of our hypotheses given that there was no relationship between altitude and sugar content, as has been observed with phenolic compounds and pipeolitic acid. The possible causes for the heterogeneous distribution of sugar could due to intrinsic factors in the production of fruits in Inga similar to those observed in other species, such as auto-incompatibility, limited resources in the production of fruits, selective abortion, and issues related to the ontogenetic development of the fruit (Koptur 1983, 1984, 1985). Also, the possible spatial overlap of several species of Inga in coffee plantations may favor cross-pollination as has been suggested by Richardson et al. (2001). It can be inferred that the heterogeneity in the sugar content in the fruit shows the lack of genetic enhancement of this fruit-tree, which opens the possibility of planning genetic improvement programs for more productive use of the seeds and fruits.

Molecular variation and altitude. The variation found in the trnL-F and ITS sequences reflects two clearly defined lineages according to the altitudinal origin of the samples. DNA sequences were homogeneous in all 12 trees sampled from the mountainous region (municipality of Coatepec, Ver.); similarly, in the 13 trees from the coastal plains (Tolome and San Pancho, municipality of Paso de Ovejas and La Antigua Ver.). However, there were important dissimilarities at the nucleotide level between both groups. The conserved indel in trees from the coastal region appears to be a synapomorphic character delimiting natural lineages as has been observed in other organisms (e.g. Calviño \& Downie 2007, Chiari et al. 2009, Soltis et al. 1998). Indels from the trnL-F region have resulted good phylogenetic markers for some taxa (e.g. Richardson et al. 2000, Holt et al. 2004, Ghamkhar et al. 2007, Drábková et al. 2004), as well as homoplasious for others (e.g. Kellermann \& Udovicic 2007). The trnL-F region is often of different length, which can make sequence alignment and the determination of homologous bases a matter of concern in phylogenetic analyses (González et al. 2006). However, considering our results we conclude that although not devoid of homoplasy, indels can be useful markers of shared history at lower taxonomic levels as in the case of Inga inicuil and I. paterno. Differences found in this 
work support previous observations based on morphological characters (Sousa 1993) suggesting that I. inicuil and I. paterno are distinct species occupying habitats at different altitudes: Inga inicuil corresponds to specimens collected from Coatepec, Ver., (range 850 to $1,530 \mathrm{~m}$ a.s.1.), while trees sampled in Tolome and San Pancho (20-50 m a.s.1.) correspond to I. paterno (Sousa 1993). Due to the clear differences found between the trees from the mountainous versus the coastal regions, it would be useful to continue the study with a detailed ethnobotanical exploration of the uses for seeds and fruits of these species by people in localities at different altitudes. Also, the remarkable differences of sequence data from the trnL-F region within the species make further research necessary, increasing taxon sampling along with its distribution range. The study of DNA variation in what popularly is called "jinicuil" in the physiographically diverse state of Veracruz, Mexico, provides useful data that help to clarify the taxonomy of this group and which in turn, considering the uses and potential food of these species, provide a firmer basis for designing sustainable management of these native fruit-trees.

\section{Acknowledgments}

Thanks to the Consejo Nacional de Ciencia y Tecnología (CONACyT-México) for the scholarships 197852 to MTPP-S, and the Colegio de Postgraduados (colpos.mx) through the research group Agronegocios, Agroecoturismo y Arquitectura del Paisaje. We thank to Griselda Benítez from INECOL for help in field work; Mario Sousa Sánchez at the herbarium MEXU (Universidad Nacional Autónoma de México in Mexico City) for identifying the Inga specimens. We also acknowledge to David Gernandt and Tom Wendt for the edition of the English language, and to Bertha Pérez and Elsa Utrera for some technical work for obtaining sequences. We also thank the use of equipment financed with project 103158 CONACyT-México to DG.

\section{Literature cited}

Altekar G, Dwarkadas S, Huelsenbeck JP. Ronquist F. 2004. Parallel Metropolis-coupled Markov chain Monte Carlo for Bayesian phylogenetic inference. Bioinformatics 20:407-415.

Altieri M, Nicholls C. 2000. Agroecología teoría y práctica para una agricultura sustentable. Serie Textos Básicos para la Formación Ambiental, Programa de las Naciones Unidas para el Medio Ambiente, México D.F.

Angelone S, Hilfiker K, Holderegger R, Bergamini A, Hoebee SE. 2007. Regional population dynamics define the local genetic structure in Sorbus torminalis. Molecular Ecology 16:1291-1301.

Bassil N, Boccacci P, Botta R, Postman J, Mehlenbacher S. 2013. Nuclear and chloroplast microsatellite markers to assess genetic diversity and evolution in hazelnut species, hybrids and cultivars. Genetic Resources and Crop Evolution 60:543-568.

Batnini M-A, Bourguiba H, Trifi-Farah N, Krichen L. 2014. Chloroplast DNA sequence data provides new insights into genetic diversity and phylogenetic relationships of Tunisian apricot germplasm. Scientia Horticulturae 178:241-247.

Baverstock PR, Moritz C. 1996. Project design. In: Hillis DM, Moritz C Mable BK, eds. Molecular Systematics. Sunderland: Sinauer, 17-47

Bressani R. 2010. Valoración química nutricional de la harina de semillas de diferentes especies de Inga (I. jinicuil I. laurina/paterno I. vera). Informe final Proyecto FONACYT-SENACYT-CONCYT. Guatemala.

Brown GK, Murphy DJ, Miller JT, Ladiges PY. 2008. Acacia s.s. and its relationship among tropical legumes, Tribe Ingeae (Leguminosae: Mimosoideae). Systematic Botany 33:739-751.

Calviño CI, Downie SR. 2007. Circunscription and phylogeny of Apiaceae subfamily Saniculoideae based on chloroplast DNA sequences. Molecular Phylogenetics and Evolution 44:175-191.

Chiari Y, van der Meijden A, Madsen O, Vences M, Meyer A. 2009. Base composition, selection, and phylogenetic significance of indels in the recombination activating gene-1 in vertebrates. Frontiers in Zoology 6:32.

Cruz-Neto O, Aguiar AV, Twyford AD, Neaves LE, Pennington RT, Lopes AV. 2014. Genetic and ecological outcomes of Inga vera subsp. affinis (Leguminosae) tree plantations in a fragmented tropical landscape. PLOS ONE 9:e99903.

Dawson IK, Hollingsworth PM, Doyle JJ, Kresovich S, Weber JC, Sotelo-Montes C, Pennington TD, Pennington RT. 2008. Origin and genetic conservation of tropical trees in agroforestry systems: a case study from the Peruvian Amazon. Conservation Genetics 9:361-372 
Drábková L, Kirschner J, Vlček Č, Pačes V. 2004. TrnL-trnF intergenic spacer and trnL intron define major clades within Luzula and Juncus (Juncaceae): importance of structural mutations. Journal of Molecular Evolution 59:1-10.

Doyle JJ, Doyle JL 1987. A rapid DNA isolation procedure for small quantities of fresh leaf tissue. Phytochemical Bulletin 19:11-15.

Excoffier L, Laval G, Schneider S. 2005. Arlequin Version 3.0: An integrated software package for population genetics data analysis. Evolutionary Bioinformatics 1:47-50.

Geilfus F. 1994. El árbol al servicio del agricultor. Manual de agroforesteria para el desarrollo rural. CATIE Enda-Caribe, Turrialba.

Ghamkhar K, Marchant AD, Wilson KL, Bruhl JJ. 2007. Phylogeny of Abildgaardieae (Cyperaceae) inferred from ITS and trnL-F data. Aliso: A Journal of Systematic and Evolutionary Botany 23:149-164.

González D. 1998. Marcadores moleculares para los estudios comparativos de la variación en ecología y sistemática. Revista Mexicana de Micología 14:1-21.

González D, Vovides AP. 2002. Low intralineage divergence in Ceratozamia (Zamiaceae) detected with nuclear ribosomal DNA ITS and chloroplast DNA trnL-F non-coding region. Systematic Botany 27:654-661.

González D, Cubeta MA, Vilgalys R. 2006. Phylogenetic utility of indels within ribosomal DNA and $\beta$ tubulin sequences from fungi in the Rhizoctonia solani species complex. Molecular Phylogenetics and Evolution 40:459-470

Groom A. 2012. Inga jinicuil. The IUCN Red List of Threatened Species 2012: e.T19893012A19999543. http://www.iucnredlist.org/details/19893012/0 (accessed April 8, 2015).

Hall TA. 1999. BioEdit: a user-friendly biological sequence alignment editor and analysis program for Windows 95/98/NT Nucleic Acids Symposium Series 41:95-98.

Holt SDS, Horová L, Bureš P. 2004. Indel patterns of the plastid DNA trnL-trnF region within the genus Poa (Poaceae). Journal of Plant Research 117:393-407.

Hollingsworth PM, Dawson IK, Goodall-Copestake WP, Richardson JE, Weber JC, Sotelo-Montes C, Pennington RT. 2005. Do farmers reduce genetic diversity when they domesticate tropical trees? A case study from Amazonia. Molecular Ecology 14:497-501

Huelsenbeck JP, Ronquist F. 2001. MRBAYES: Bayesian inference of phylogenetic trees. Bioinformatics 17:754-755.

Karp A, Kresovich S, Bhat KV, Ayad WG, Hodgkin T. 1997. Molecular tools in plant genetic resources conservation a guide to the technologies PLGRI International Plant Genetic Resources Institute, Rome.

Kellermann J, Udovicic F. 2007. Large indels obscure phylogeny in analysis of chloroplast DNA (trnL-F) sequence data: Pomaderreae (Rhamnaceae) revisited. Telopea 12:1-22.

Kite G. 1997. Non-protein amino acid chemistry. In: Pennington TD, ed. The genus Inga: Botany. Kew: Royal Botanic Gardens, 35-70.

Koptur S. 1983. Flowering phenology and floral biology of Inga (Fabaceae Mimosoideae). Systematic Botany 8: 354-368.

Koptur S. 1984. Outcrossing and pollinator limitation of fruit set: breeding systems of neotropical Inga trees (Fabaceae Mimosoideae). Evolution 38:1130-1143.

Koptur S. 1985. Alternative defenses against hervibores in Inga (Fabaceae Mimosoideae) over an elevation gradient. Ecology 66:1639-1650.

Kursar TA, Dexter KG, Lokvam J, Pennington RT, Richardson JE, Weber MG, Murakami ET, Drake C, McGregor R, Coley PD. 2009. The evolution of antiherbivore defenses and their contribution to species coexistence in the tropical tree genus Inga. Proceedings of the National Academy of Sciences of the United States of America 106:18073-18078.

Martínez-Castillo J, Zizumbo-Villarreal D, Perales-Rivera H, Colunga-GarcíaMarín P. 2004. Intraspecific diversity and morpho-phenological variation in Phaseolus lunatus L. from the Yucatan Peninsula Mexico. Economic Botany 58:354-380.

Martínez-Moreno E, Corona-Torres T, Avitia-García E, Castillo-González AM, Terrazas-Salgado T, Colinas-León MT. 2006. Caracterización morfométrica de frutos y semillas de nanche (Byrsonima crassifolia (L.) H.B.K.). Revista Chapingo Serie Horticultura 12:11-17.

Morton CT, Zektzer AS, Rife JP, Romeo JT. 1991. Trans-4-methoxypipecolin acid, an amino acid from Inga paterno. Phytochemistry 30:2397-2399.

Parker PG, Snow AA, Schug MD, Booton GC, Fuerst PA. 1998. What molecules can tell us about populations: Choosing and using a molecular marker. Ecology 79:361-382.

Pennington RT, Sarukán J. 1998. Árboles tropicales de México. Manual para la identificación de las principales especies. Ciudad de México: Universidad Nacional Autónoma de México/Fondo de Cultura Económico.

Pennington TD. 1997. The genus Inga: Botany. Kew: Royal Botanic Gardens. 
Received:

August 10th, 2015

Accepted:

December 14th, 2015
Pulido-Salas MT. 2009. Inga jinicuil (“jinicuil”) en Coatepec, Ver., México, como árbol frutal nativo: potencial económico y factores que afectan su permanencia. Tesis de Doctorado, Colegio de Postgraduados - Campus Veracruz, Tepetates, Veracruz, México.

Pulido-Salas MT, Equihua M, Pérez-Vázquez A. 2013. Inga jinicuil (jinicuil) como árbol frutal nativo: valor comercial, calidad de frutos y valor cultural como determinantes para permanecer o ser eliminados. In: Reyes-Cervantes H, Ibarra-Contreras M, Loya-Monares N, eds. Matemáticas, Estadística y Medio Ambiente. Puebla: Benemérita Universidad Autónoma de Puebla. 54-65.

Richardson JE, Fay MF, Cronk QCB, Bowman D, Chase MW. 2000. A phylogenetic analysis of Rhamnaceae using $r b c \mathrm{~L}$ and $t r n \mathrm{~L}-\mathrm{F}$ plastid DNA sequences. American Journal of Botany 87:1309-1324.

Richardson JE, Pennington RT, Pennington TD, Hollingsworth PM. 2001. Rapid diversification of a species-rich genus of neotropical rain forest trees. Science 293:2242-2245.

Ricker M, Hernández HM, Sousa M, Ochoterena H. 2013. Tree and tree-like species of Mexico: Asteraceae, Leguminosae, and Rubiaceae. Revista Mexicana de Biodiversidad 84:439-470.

Robledo-Martínez JD. 2003. Caracterización genética de germoplasma de macadamia (Macadamia spp.). Tesis de Maestría. Colegio de Postgraduados, Montecillo, Estado de México, México.

Rollo A, Lojka B, Honys D, Mandák B, Chia Wong JA, Santos C, Costa R, Quintela-Sabarís C, Ribeiro MM. 2016. Genetic diversity and hybridization in the two species Inga ingoides and Inga edulis: potential applications for agroforestry in the Peruvian Amazon. Annals of Forest Science 73:425-435.

Ronquist F, Huelsenbeck JP. 2003. MrBayes 3: Bayesian phylogenetic inference under mixed models. Bioinformatics 19:1572-1574.

Schierenbeck KA, Skupski M, Lieberman D, Lieberman M. 1997. Population structure and genetic diversity in four tropical tree species in Costa Rica. Molecular Ecology 6: 137-144.

Soltis DE, Soltis PS, Doyle JF. (eds.) 1998. Molecular Systematic of Plants II: DNA sequencing. New York: Kluwer Academy Publishers.

Sousa MS. 1993. El género Inga (Leguminosae: Mimosoideae) del sur de México y Centroamérica, estudio previo para la Flora Mesoamericana. Annals of the Missouri Botanical Garden 80:223-269.

Sousa M. 2001. Inga. In: Stevens WD, Ulloa Ulloa C, Pool A, Montiel OM, eds. Flora de Nicaragua Vol. 2, Angiospermas (Fabaceae-Oxalidaceae). St. Louis: Monographs in Systematic Botany from the Missouri Botanical Garden, 1467-1483.

Sousa M. 2009. Adiciones al género Inga (Ingeae, Mimosoideae, Leguminosae) para la Flora Mesoamericana. Acta Botanica Mexicana 89:25-41.

Taberlet P, Gielly L, Pautou G, Bouvet J. 1991. Universal primers for amplification of three non-coding regions of chloroplast DNA. Plant Molecular Biology 17:1105-1109.

Thompson JD, Higgins DG, Gibson TJ. 1994. CLUSTAL W: improving the sensitivity of progressive multiple sequence alignment through sequence weighting, position-specific gap penalties and weight matrix choice. Nucleic Acids Research 22:4673-4680.

Vázquez-Yanes C, Batis-Muñoz AI, Alcocer-Silva MI, Gual-Díaz M, Sánchez-Dirzo C. 1999. Árboles y arbustos nativos potencialmente valiosos para la restauración ecológica y la reforestación. Comisión Nacional para el Conocimiento y Uso de la Biodiversidad, Ciudad de México.

White TJ, Bruns T, Lee S, Taylor J. 1990. Amplification and direct sequencing of fungal ribosomal RNA genes for phylogenetics. In: Innis MA, Gelfand DH, Sninsky JJ, White TJ, eds. PCR Protocols a guide to methods and applications. San Diego: Academic Press, 315-322

Zwickl DJ. 2006. Genetic algorithm approaches for the phylogenetic analysis of large biological sequence datasets under the maximum likelihood criterion. PhD. Thesis, University of Texas at Austin, Austin, Texas. 